\title{
WORLD VIEW
}

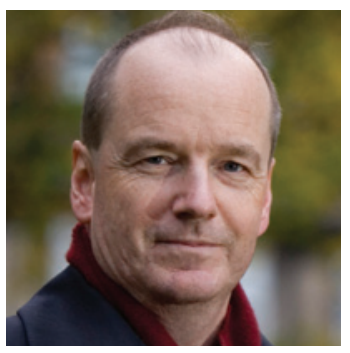

\section{The unlikely wisdom of Chairman Mao}

\author{
Self-criticism is a virtue seldom possessed by men, and never by \\ the leaders of Western science, says Colin Macilwain.
}

$\mathrm{F}$ ormer Chinese leader Mao Zedong is remembered in the West as a monster. But he had at least one good idea - and it's one that those who speak for science should pick up on, and fast.

At the annual meeting of the American Association for the Advancement of Science (AAAS) in Boston, Massachusetts, last month, Rongping Mu of the Chinese Academy of Sciences ran through a searing litany of how China still lacks innovative capacity. As he did so, I thought of Chairman Mao, and his doctrine of self-criticism.

Instead of bragging about his country's growing scientific spending and prowess, Mu dwelt on its innovative weaknesses. He presented figures from the Organisation for Economic Co-operation and Development suggesting that China lags behind countries such as Russia and Turkey in its overall readiness to innovate.

What really caught my attention was that the guy from Japan stood up and did the same thing. Terutaka Kuwahara of the National Institute of Science and Technology Policy in Tokyo stressed deficiencies and weaknesses in the Japanese system. Ten years ago, you'd have been lucky to get this kind of self-criticism from a policy wonk speaking privately in Tokyo, never mind publicly in Boston.

Some time ago, the government of Singapore published a report that assessed the success and impact of various scientific initiatives in that country in pretty brutal terms. It found, for example, that the life sciences weren't creating jobs in the way that engineering was. A major revamp of the initiatives followed promptly.

One problem that Western science and technology faces is that this kind of analysis and action happens rarely in Europe, and never in the United States. It isn't that American culture is averse to self-criticism. In 1991, John Akers, then chairman of IBM, delivered a scathing talk, leaked to the press. I can still recall some of his words: "Too many people here hanging around the water-cooler...”. Akers was later fired, but his harsh assessment helped prepare IBM to rebuild itself and to dodge the Internet iceberg that sank most of its old-time computing rivals.

And in 1995, a grizzled Motorola engineer called Bob Galvin was invited by the young, and possibly naive, Clinton administration to examine the performance of the US national laboratories run by the Department of Energy, NASA and the Department of Defense. His committee produced a scathing assessment. Galvin wanted Congress to pre-approve a commission that would assess, and close, some of these places. Since then, the report has gathered a lot of dust, and perhaps as much as US $\$ 100$ billion has been poured down the drain to keep these labs open.

Nowadays, such critiques are notable for their

\section{DNATURE,COM}

Discuss this article online at:

go.nature.com/vpl2ms absence. The argument, advanced at the AAAS meeting, that a heavily indebted and politically dysfunctional United States can shortly resume its twentieth-century growth pattern, if only it keeps investing in research and development (R\&D), strains credulity.

In a session devoted to the connections between basic research funding and economic growth, no one produced a single paper or reference to support this argument. So I fished out some data of my own: in the year 2000, China spent about $\$ 25$ billion on R\&D and produced 3\% of the global scientific literature. The United States spent around $\$ 300$ billion on $\mathrm{R} \& \mathrm{D}$ and produced $27 \%$ of the papers. Thirteen years later, the Chinese economy has expanded by $200 \%$; the American one by $20 \%$. Clearly the two economies are not directly comparable, but curiosity-driven research on an industrial scale is a relatively recent invention, and I would suggest that it may be a sign — rather than the cause - of a successful economy.

I'm still waiting to see a $\mathrm{PhD}$ thesis - never mind a National Academies report - on the economic or health outcomes of the doubling of funding for the US National Institutes of Health from 1998 to 2003.

Over a pizza in Boston, I asked an old pal, who knows US science policy as well as any man alive, when he thought this troubling mist of complacency would lift. He offered the opinion that the pending money crunch and the economic challenge from China may soon prompt a change of tack.

As a Brit who spent 12 years in Washington DC, I'm not so sure. British scientists do well at getting papers published in high-profile journals, but this apparently impressive science base does not drive strong economic performance. Lately, Germany has enjoyed an export boom, whereas British exports have stagnated, despite a drastic $30 \%$ currency devaluation since 2008 , because there is little productive capacity left in its economy. The leaders of British science, understandably, prefer to concentrate on its strengths rather than its weaknesses, and this is the trap into which the United States is also falling.

America needs to take a leaf from East Asia's book and take a cold, hard look at how it spends its money - including the vast federal R\&D budget. As for Chairman Mao, he'd have cheered a report from the Xinhua news agency on 6 February. The story, "Frugality fuels science breakthrough", lauded a team of neutrino scientists for, among other things, finding cheap accommodation. I've never seen a story along these lines in Europe or the United States. And that, I'm afraid, suggests that decadence has set in.

Colin Macilwain writes about science policy from Edinburgh, $U K$. e-mail:cfmworldview@gmail.com 